\title{
Preserving the Catholics of the Holy Land or Integrating Them into the Palestine Nation $(1920-1950)$ ?
}

\author{
K.M.J. Sanchez Summerer
}

To British officials, Jerusalem appeared to be a divided city, with its different ethnic and religious groups, they saw it as a vivid image of 'Babel alive.' Ronald Storrs, the governor of Jerusalem, underlined the multilingualism of pupils when he visited the French Catholic school of the Collège des Frères, and the 'harmony' between the pupils of different religions studying together. ${ }^{2}$ This diversity presented a challenge for the British administrators who, from the early years of the Mandate, sought to expand and separate the educational system along linguistic lines; as a consequence, the division of public space became more prominent. ${ }^{3}$ Empowered by its role as official protectorate of the Christians in the Levant, France played an important role in what it perceived to be the "preservation of the Catholic community/minority of the Holy Land." 4 French Catholic schools proposed one education for Christians, which was opened to Jews and Muslims from the beginning of the twentieth century onwards; these schools, set up before the Mandate (1904), challenged the governmental education offered during the first years of the Mandate.

1 The religious and ethnic groups and the cacophony of languages were perceived as "one of the principal attractions," John de V. Loder to mother, 4 May 1918. Private Papers Collection, Middle East Centre, St Antony's College, Oxford; quoted in J. Sherman, Mandate Days: British Lives in Palestine, 1918-1948 (Baltimore: Johns Hopkins University Press, 1997), 38.

2 ACJ (Archives of the Jerusalem College of the Brothers of the Christian schools-Frères des écoles chrétiennes, Jerusalem), Historique, 1926, "note de Ronald Storrs."

3 Laura Robson, Colonialism and Christianity in Mandate Palestine (Austin: University of Texas Press, 2011).

4 It is not our intention to discuss the concept of 'minority' here. We refer to Benjamin Thomas White and his general argument, according to which the political concept of "majorities" and "minorities" makes sense only in the context of the modern state, especially the nation state. We focus more on how the Catholics saw themselves between the two wars. Benjamin Thomas White, The Emergence of Minorities in the Middle East, the Politics of Community in French Mandate Syria (Edinburgh: Edinburgh University Press, 2012). 
In this paper I reveal a neglected aspect of colonial linguistic and religious policy governing the Catholics of the Holy Land, the impacts of French Catholic education on the identity-building process carried out in Palestine, and their reception by the Palestinian Catholic community. I focus on a discussion of the missionary schools as public and communal spaces, meeting places for missionaries, the elite, the middle classes, colonial, and religious powers. I also seek to understand how language practices, beliefs, and management intersect with religious beliefs, convictions, and ideologies at the local and international levels; the ways in which dominant discourses about language and education were played out, negotiated through Catholic schools and their environment, and I attempt to envisage the effect of a conflict in the conceptualization of language as a tool, at the individual and group level.

How did France use its schools as a platform, as a French spearhead in the Holy Land to confront Great Britain? How did the French language act as both a 'temporal' and 'spiritual' asset to the Christian community, but also, to a certain extent, to the Jewish and Muslim communities? How did the Roman and local Catholic actors perceive and use language as a tool for the defense of the interests of the Catholic community? How did the local Catholic community react to this religious language policy?

In the recent publications on Christianity in British Mandate Palestine, the category of Palestinian Christian Orthodoxy has been studied more than the Palestinian Catholic communities, though the latter were fundamental during the growth of international institutions in Palestine and were instrumental to France, and to a lesser extent to Italy, during and even after the establishment of the protectorate for the Christians of the Holy Land. Thus far, the linguistic aspects of the various Christian identities have been neglected. Historians agree on the important role of Arab Christians during the Mandate, but disagree on how Christians fit into the wider Arab society and to what degree they relied on their religious affiliation at certain times. Works dealing with Catholics in Palestine are for the most part interested in the holy places, diplomacy, politics, and religion, while the history of education and language use of indigenous Catholics have yet to be explored. ${ }^{5}$ While the major works of Y. Porath and D. Tsimhoni on Palestinian nationalism and Christians are based on British interpretations of Arab society and highlight the intercommunal discord, ${ }^{6}$ the work of B. Spolsky and R. Cooper do not tackle the Catholic commu-

5 דבורה ,אדן, הבריטי המנדט בתקופת בפלשתינה הערבי החינוך, 1989, 370.9 (91) E3.

6 Daphne Tsimhoni, "The Arab Christians and the Palestinian Arab National Movement during the Formative Stage," in G. Ben-Dor (ed.), The Palestinians and the Middle East Conflict 
nity's use of languages during the Mandate period in relation to their Muslim and Jewish fellows, nor does the recent work of Haiduc-Dale on Christian communities and communalism. ${ }^{7}$

Despite the close link between the preservation of and further dissemination of the French language and the promotion of the Catholic religion in Palestine under Ottoman and British rules, this aspect of colonial linguistic policy has not been studied before; 8 the focus until now has been on Egypt, Syria, and Lebanon. The impact of language policies on Palestine has been underrated in the different historiographies despite the conspicuous nature of the European legacy in Palestine and despite the linguistic motivation of missionary education, cited since the 1950s. More recently, Aslanov in his analysis of the position of the French language in the Levant, maintained that religious factors were more decisive than political ones in preserving the language. ${ }^{9} \mathrm{He}$ demonstrated that the 'preservation,' and the 'revival' of French was not necessarily based on an administrative or military occupation, and that the Levantine Francophone communities should not be considered a simple corollary of colonial and imperial policies, as it had been deeply rooted in this area before France entered onto the scene. However, he did not expand upon the part played by the schools in the area.

(Ramat Gan: Turtledove Publishing, 1978), 73-98 and Yehoshuah Porath, The Emergence of the Palestinian-Arab National Movement, 1918-1929 (London: Cass, 1974) both believe that Christians did not organize communally and this led to an overall decrease in Christians' importance throughout the Mandate.

7 Bernard Spolsky and Robert Cooper, The Languages of Jerusalem (Oxford: Clarendon Press, 1991) and Noah Haiduc-Dale, "Arab Christians in Palestine Communalism and Nationalism, 1917-1948" (PhD diss., New York University, 2010).

8 This absence could be explained by the fact that the study of French in Egypt has been prevalent in the historiography of the French presence in the Levant, and in the study of the traditional links between the Maronites of Lebanon and the French language. The Palestinian case, which occupies a separate place though it remains in the Levantine Francophonie, has been forgotten. Benjamin Fortna, Imperial Classroom: Islam, the State and Education in the Late Ottoman Empire (Oxford: Oxford University Press, 2002); John E. Joseph, Language and Identity, National, Ethnic, Religious (New York: Palgrave Macmillan, 2004); John Myhill, Language, Religion and National Identity in Europe and the Middle East (Amsterdam: John Benjamins, 2006); Jean Riffier, Les ouvres françaises en Syrie—1860-1923 (Paris: L' Harmattan, 200o); Laura Robson, Colonialism and Christianity in Mandate Palestine; Heather Sharkey, American Evangelicals in Egypt: Missionary Encounters in the Age of Empire (Princeton, NJ: Princeton University Press, 2008).

9 Cyril Aslanov, Le français au Levant, jadis et naguère. A la recherche d'une langue perdue (Paris: Honoré Champion, 2006). 
Historical sociolinguistic studies of the Jerusalem communities and their relations in the public space face specific challenges that relate to historical inquiry; they contend with sometimes unreliable sources, with limited access to reliable spoken language data, and "imperfect data."10 The present study is based on primary and secondary published sources and archival material. The Latin Patriarchate and Vatican archival material on the Palestinian Catholic community question whether the current studies on Catholics is representative of the variety of cultural and linguistic choices made by the Catholics during the British Mandate period. In order to understand the social and cultural dimensions of the use of languages in the Catholic communities, in contact with other communities, I have based my analysis on the private archives and photographs provided by various French schools, ${ }^{11}$ as well as the Latin Patriarchal archives, the Congregation for Oriental churches archives (part of the Holy See archives), the Vatican Secretariat of State archives, the Sainte Anne Melkite seminar of Jerusalem archives, and the files of the Chief Secretary of the Palestine government. ${ }^{12}$ In this paper I have tried to include the Catholic

10 Brian D. Joseph, "Historical Linguistics and Sociolinguistics: Strange Bedfellows or Natural Friends?," in Language and History, Linguistics and Historiography, ed. Nils Langer, Steffan Davies, and Wim Vandenbussche (New York: Peter Lang, 2012), 70.

11 Few memoirs of the schools' alumni and magazines were published to voice the indigenous perspective on missionary educative activities, in contrast to the ones available in the Lebanese and Egyptian cases. Some of the archival material was preserved and classified during a project ("Archiver au Moyen-Orient, faiseurs d'histoire, faiseurs d' archives," 2006-2008) entered into with the French consulate, the French Ministry of Foreign Affairs Archives Department, and the French National Research Agency CNRS (Centre national de la recherche scientifique), in order to preserve and classify the archives of these schools still remaining. The loss of certain archives can be partially explained by the political events that have affected the schools, such as the 1947-1948 and 1967 wars.

12 The following acronyms will be used: Асв (Archives of the Bethlehem College of the Brothers of the Christian schools, Bethlehem); ACJ (Archives of the Jerusalem College of the Brothers of the Christian schools—Frères des écoles chrétiennes, Jerusalem); ACTs (Archives of the Custodia di Terra Santa, Jerusalem); AmAE (Archives of the French Ministry of Foreign Affairs, Paris and Nantes); AMg (Archives of the General House of the Brothers of the Christian schools, Rome); Assj (Archives of the Sisters of Saint Joseph, Jerusalem); ANDS (Archives of the Sisters of Zion, Jerusalem and Rome); ASC (Archives of the Sisters of the Charity, Soeurs de la Charité, Paris); ввDE (Blue Books, Government of Palestine, Department of Education); cocA (Congregation for Oriental Churches archives, Congregatio Pro Ecclesiis Orientalibus); LPA (Latin Patriarchate Archives, Jerusalem); JssA (Jerusalem Schmidt Schule archives); MECA (Middle East Centre Archives, Oxford), PROFo or wo (Public Record Office, Foreign Office or War Office, United Kingdom); SASA (Sainte Anne Seminar archives); and vssA (Vatican Segretaria di Stato archives). 
subnarrative and the possibility that it used religious identification in political decision-making and societal relations (attempts to establish, resist, or modify language policies 'from below'). Local Catholic community archives (schools, Latin Patriarchate and Melkite seminar archives) are underused resources for Mandate era studies, while the Mandate archives give greater nuance to the study of the writings of the Catholic community.

Histories of public space in the Holy Land tend to describe events as macrolevel phenomena. More recent works point out the important role of languages in Jerusalem public space and the different combinations in the old city of Jerusalem (the new part of the town was more "cloisonné"). ${ }^{13}$ Examining these phenomena through the lens of daily school life provides a counter voice and offers an account of different kinds of combinations and competitions. ${ }^{14}$

Here I envisage the French schools as public, communal, and to a lesser extent, private spaces. I focus on two main French Catholic schools that were strategically located inside the old city of Jerusalem: the Collège des Frères, situated near the New Gate opened in 1889, it was on the road of many Catholic pilgrimages and on the line of separation between fighters in 1948 and 1967; the second school was the Melkite (Greek Catholic) seminar and boys' school of Sainte Anne, situated on the Via Dolorosa, the French 'lieu de mémoire' in Jerusalem. ${ }^{15}$ Under French jurisdiction, it symbolized the 'eternal' links between France and the oriental Catholics, where French pilgrims gathered in 1853 and the meeting place of the French community in Jerusalem. ${ }^{16}$

13 Y. Wallach in his chapter in this volume examines the possibility of evoking "shared spaces" in pre-1948 Jerusalem. He argues, as does Salim Tamari, that the Old City was far more mixed in confessional terms than the European descriptions tend to present it. Oral history and some memoirs of pupils of these Catholic schools point out these intercommunal moments between Catholics, other Christian communities, and Muslims, also more often in the domestic space than in the public space. Here we focus on the contacts in and around the two schools in the Old City. During the 1920s, the wealthier families moved to the new part of town, while holding on to their family properties in the Old City.

14 Salim Tamari and Issam Nassar (eds.), al-Quds al-intidābiyya fíl-mudhakarātal-jawhariyya (Jerusalem: Institute of Jerusalem Studies, 2005) and Salim Tamari, Year of the Locust, A Soldier's Diary and the Erasure of Palestine's Ottoman Past (Berkeley: University of California Press, 2011).

15 Dominique Trimbur, "Sainte Anne, lieu de mémoire et lieu de vie français à Jérusalem," in Chrétiens et sociétés-XVIe-XXe siècles, $\mathrm{n}^{\mathrm{o}} 7$ (2000), 39-69. The author analyzes the political context of the French presence in Sainte Anne and the French political representation via the area of the Church of Sainte Anne.

16 SASA, 2a1, La vie du séminaire des origines à la guerre de 1914-1918, "la France de Saint 
I begin by analyzing the Catholic communities and their importance for the European presence, linguistic policy of the Catholic communities, and missionary education policy in the Holy Land. I will then focus on the linguistic and proto-national British agenda in Palestine, the educational and linguistic conflict between France and Great Britain, and its consequences for the process of identity formation in the Catholic schools and on the links between language and religion in educational policies. Finally, I examine the indigenous Catholic reaction to the European presence and the Catholic perception of the role of Arabic as a common ground with the Palestinian Muslim population.

\section{The Palestinian Catholic Communities and the Jerusalem Educational Space}

\section{Catholic Communities, European Powers in Palestine, and Educational Challenges}

Considered the Holy Land by Christian European countries, from the midnineteenth century onwards Palestine became the theatre of European rivalries and interference. ${ }^{17}$ For Great Britain, Palestine constituted the link between Egypt, Iraq, and India, and the "holy city."18 For France, who considered itself as the 'fille ainée de l'Eglise' (the eldest daughter of the Catholic church) and the protector of the Christian minorities in the Middle East, Palestine was perceived as an essential area, near the French sphere of influence over Syria and Lebanon, and as the "most French Land of the Levant."19 The Sykes-Picot agreements (1916) redrew the geopolitical map of the Middle East and considered Palestine an international zone, and the Treaty of Sèvres (1920) placed Pales-

Louis," "la France éternelle" are evoked for both the Melkite seminar, the boys' school, and the church of Sainte Anne.

17 Henri Laurens, La question de Palestine (1922-1947). Une mission sacrée de civilisation (Paris: Fayard, 2002); Dominique Trimbur, "Catholiques français et allemands en Palestine, XIXexxe siècles," Bulletin du Centre de recherche français de Jérusalem 18 (2007) 92-106; Anthony O'Mahony, "The Latins of the East: The Vatican, Jerusalem and the Palestinian Christians," in The Christian Communities of Jerusalem and the Holy Land: Studies in History, Religion and Politics, ed. Anthony O'Mahony (Cardiff: University of Wales Press, 2003), 90-114.

18 Ethan Bar-Yosef, The Holy Land in English Culture, 1799-1917: Palestine and the Question of Orientalism, (Oxford: Clarendon Press, 2005).

19 Maurice Barrès, Une enquête aux pays du Levant (Paris: Plon-Nouritt, 1923). Laurens, La question de Palestine. 
tine under the responsibility of the British government, bringing a de facto end to the French protectorate for Catholics (it ended de jure in 1924). ${ }^{20}$

The French Catholic schools were at the forefront of a renewal in education and among the oldest European educational institutions in Palestine. The Tanzimat reforms of 1869 led to the development of public schools (umumiyya $)^{21}$ and the professionalization of western education; ${ }^{22}$ the Ottoman reformers adopted a law that made elementary schooling compulsory for Ottoman citizens for a minimum period of three years and provided education that was no longer primarily religious. ${ }^{23}$ Europeans thus came to perceive Palestine, and especially Jerusalem, as an educational arena. ${ }^{24}$ However, the commercial and industrial French presence remained less developed than in the coastal towns of Palestine, ${ }^{25}$ and the inner cities of Palestine offered fewer public educational structures. ${ }^{26}$ Taking the reforms as an opportunity to spread French education throughout Palestine, the French schools proposed a curriculum — both classical and professional — valued by the Ottoman authorities; ${ }^{27}$ the last quarter of the twentieth century saw the rapid growth of the French congregations teaching in French, then recognized by the Ottomans as a semi-official language. The French Catholic establishments opened rapidly across the Palestinian territory (one school opened every two to three years until 1904). The brothers of the Christian schools and the sisters of Saint

20 The French Protectorate of Catholics takes its roots in the Capitulations given to France and its citizens (ressortissants) — commercial, religious, juridical favors—in 1575; Catherine Nicault, Jérusalem 1850-1948, des Ottomans aux Anglais, entre coexistence spirituelle et déchirure politique (Paris: Autrement, 1999).

Divided into primary (ibtidāiyya, created in 1890) and secondary schools (rushdiyya, created in 1902); Fortna, Imperial Classroom.

22 The French order of the Brothers of the Christian schools, from Jean Baptiste de la Salle, were asked to help the Ottoman authorities to implement training schools for boys, AMG, NH701.

23 Rashid Khalidi, Palestinian Identity, the Construction of a Modern Identity (New York: Columbia University Press, 1997), 86.

24 ACJ, Report of the German Archeological Institute, Schools for Arabs (Jerusalem, 1905).

25 Frederique Schillo, "Les commerçants français en Palestine pendant la période ottomane," in De Bonaparte à Balfour, la France, l'Europe occidentale et la Palestine, 1799-1917, ed. Dominique Trimbur and Ran Aaronsohn (Paris: CNRs editions, 2008), 135-167.

26 Fortna, Imperial Classroom, 136. French schools were not intended for French nationals as there were only few in Palestine.

27 The 1901 Mytilène and the 1913 Constantinople agreements (for the preservation of the rights of the Christian communities) gave schools that were established without official permits the right to continue to function. 
Joseph's establishments enrolled the majority of the Christian students. ${ }^{28}$ In 1895 private schools outweighed public schools, among the private institutions the French schools preponderated. ${ }^{29}$ These schools aimed to educate not only boys, but girls as well, and this relatively early when compared to the laws on girls' schools (of 1867) in France.

Competition with other missionary institutions, especially the British schools, ${ }^{30}$ began in the 1860 s for primary education, and at the end of the nineteenth century for secondary institutions. The French educational model operated differently than the German and English systems, which held that the pupil's mother tongue had to be mastered before any other language teaching could take place. ${ }^{31}$ The Germans and English were unsettled by the concern that teaching French would create a "confused linguistic identity" and become a sign of the "degeneration" of Palestinian society, ${ }^{32}$ they focused on Arabic, while the Catholics presented French (until 1920) as the language of Catholicism. Furthermore, different Christian communities (Catholic and Orthodox) opted for French Catholic institutions because they did not have community schools. ${ }^{33}$

28 The most important French Catholic educational facilities established in Palestine (boys and girls) were the following: Saint Joseph Sisters schools: 1848 Jerusalem (1849 Jaffa, 1853 Bethleem, 1872 Ramleh, 1873 Ramallah, 1875 Beit Jalah, 1889 Nazareth, 1904 Naplouse). The Dames de Nazareth was established in Nazareth in 1855 but nowhere else in Palestine, followed in 1856 by the Zion Sisters. The Brothers of the Christian schools (Frères des Ecoles Chrétiennes) started by opening a school in Jerusalem in 1876 , then the main cities of Palestine followed; 188o Rosary Sisters (Soeurs du Rosaire); 1883, Fathers of Zion (Pères de Sion), 1886 the Charity Sisters (Filles de la Charité, Saint Vincent de Paul); Karène Sanchez, Politiques, éducation et identités linguistiques, le college des frères des écoles chrétiennes de Jérusalem, 1922-1939 (Utrecht: LOT, 2009), annexes.

29 Vital Cuinet, La Turquie d'Asie, géographie administrative, statistique descriptive et raisonnée de chaque province de l'Asie mineure (Paris: E. Leroux, 1895), 563; Cuinet indicates that of the schools for the Jerusalem region there were 8 public, 27 Catholic, 5 Protestant, and 3 Orthodox.

3o German and Russian institutions had two schools during the Ottoman period, and these were partially closed after World War I. Italians did not run their own schools in the Bethlehem and Jerusalem areas, but their influence was predominant in the Franciscan schools for the poor Christian population.

Hans-Georg Wolf, "British and French Languages and Educational Policies in the Mandate and Trusteeship Territories," Language Sciences 30, no. 5 (2008), 553-574.

32 ACJ, Report of the German Archeological Institute, Schools for Arabs (Jerusalem).

33 The Latin Patriarchate and the Custodia di Terra Santa archives contain educational censuses. They show that the Sisters of Saint Joseph and to some extent, the Brothers of the Christian schools worked partly for the local Catholic authorities, but also opened their 
In the field of language education, the European powers competed fiercely. In the late nineteenth century, knowledge of languages was a way of accessing 'modernity.'34 Each European institution claimed preeminence in addressing its linguistic and religious community. Fully aware of the linguistic acquisition process as a marker of identity, France and Great Britain confronted one another through their respective educational systems and also through the local schools 'inspired' by the French and British models. French linguistic and cultural influence constituted a response to British linguistic and educative initiatives. ${ }^{35}$ The Italian influence on the Catholic community, essentially via the Custodia di Terra Santa who 'insured' the protection of the Catholics until the rebirth of the Latin Patriarchate in 1847 , was manifest in the spread of Italian in the Franciscan schools; this lasted until the mid 1920s. ${ }^{36}$

For the French public and its government, in the early 1920 Palestine remained "the most French land of the Orient," at a time when the loss to Great Britain of the French Catholic protectorate in the Holy Land was confirmed, and the French therefore focused on the schools to preserve their influence. ${ }^{37}$ Even during British Mandatory rule, the French General Consulate continued to support French educational work and assisted the French communities, which were viewed by French officials to be "its residual influence in the Holy Land." 38

own private sections that offered a more diverse curriculum; ACTs, Sisters of Saint Joseph and Brothers of the Christian schools files.

34 Keith David Watenpaugh, Being Modern in the Middle East: Revolution, Nationalism, Colonialism, and the Arab Middle Class (Princeton, NJ: Princeton University Press, 2006).

$3^{6}$ vssA, $5^{1}$ P.O. $5^{6-57}, 1924$, Missione straordinaria di Mons. Doci in Turchia, promemoria del Sig. Schiaparelli, Secretario Generale del Associazione Nazionale per soccorere i missionari italiani: proposte per la laicizzazione della scuole religiose; vssA, 81 Po 87 Palestina 1927-1938 Attegiamento dei Consoli, Note del Nuovo Console Generale italiano A Gerusalemme Orazio Pedrazzi. 'il Levante mediterraneo e l'Italia', 'Custodia e Italia', 1927. For the Italian linguistic and cultural agenda during the Ottoman period, cf. Pieraccini Paolo, "Schiaparelli e i Francescani. Fondazione e primi passi dell'Associazione Nazionale per Soccorrere I Missionari Italiani (1886-1905)," Studi Francescani, vol 112, pp. 71-137.

AMAE, E312-1, R. de Caix to the Minister of Foreign Affairs, 19 May 1920. From 1926, her specific prerogative was restricted to the "reception of the liturgical honours" by French representatives when entering Catholic churches.

38 In a letter to the Minister of Foreign Affairs, Robert de Caix, collaborator of the Civil French High Commissioner in Syria and Lebanon and primarily responsible for the development of French policy in the Levant, stated that "[i]t is in the preservation of religious insti- 
French Catholic schools acted as a 'spearhead' for French linguistic and cultural policy in the Holy Land. ${ }^{39}$ The French missionaries were indeed perceived as French 'agents' by the British authorities. ${ }^{40}$ Both schools appeared as French places and spaces that were marked symbolically by flags, personnel, hymns, and cultural references in the classrooms. The presence of French pilgrims ("a pre 1789 French Revolution taste of France") and the fanfare of Sainte Anne's school band playing French republican and Catholic hymns was supported by the alumni and members of religious associations wearing banners written in French and Arabic. ${ }^{41}$

\section{Linguistic Challenges of a Diverse Community: Catholic Schools as Spaces of Encounter?}

In his study of the construction of a Palestinian identity, Khalidi showed that in Palestine a (single) language did not always correspond to a (single) religious community, and he highlighted their overlapping identities. ${ }^{42}$ The linguistic landscape of Jerusalem was indeed characterized, at the end of the Ottoman period, by a coexistence of Turkish (the official language of the empire, which was spoken by relatively few outside what is now Turkey), ${ }^{43}$ Arabic (the language of the majority and the language of instruction in Ottoman schools), Yiddish, Hebrew, Greek, Armenian (languages of ethnic minorities), and languages of the colonial powers such as French, English, and German (dominant languages in terms of social prestige, but minority languages in terms of the number of speakers).

tutions and the French character of their teaching that we must focus our efforts. This is what constitutes our residual influence in the Holy Land." Robert de Caix to the Minister of Foreign Affairs, La position de la France en Palestine, 28 Oct. 1920, AMAE, 312-1, $\mathrm{n}^{\circ} 404$.

AMAE, E 312-1, $n^{\circ} 90$, Rapport du vice-amiral de Bon, 14/og/1920; AMAE, Nantes, B, 200, nº84, Consul of Jerusalem, Rais, to Aristide Briand, MAE, 15 June 1921; AMAE, E 312-32, $\mathrm{n}^{\circ}{ }_{10}, 2$ July 1928.

40 PRO, WO, 106/189, GS1, Advanced French Propaganda in Jerusalem.

41 COCA, LPA, and SASA photographic archives.

42 Khalidi, Palestinian Identity.

43 In 1910: 3,56o Roman Catholics, 12,00o Muslims, 5,900 Greek Catholics, 1,60o Protestants. In 1922, the Catholics represented 25 percent of the Jerusalem-Jaffa area population, while the Melkites constituted 40 percent of the population of the northern district; Justin McCarthy, The Population of Palestine: Population History and Statistics of the Late Ottoman Period and the Mandate (New York: Columbia University Press, 1988). LPA, 1.1 B, LB, Melkites, 1936: in the Jerusalem area: 29,679 Latins, 21,80o Melkites, 36o Armenians, $35^{\circ}$ siro puro (Syriac Catholic Church), a total of 52,389 Catholics. 
The Catholic community characterized itself by its multilingualism, which highlights its shifting motivations, its communal self-understandings, and the complexity and elasticity of its linguistic identities. The community indeed used French and Italian as languages of instruction, while Arabic remained the main language of daily communication until the end of the 1920 .

Significantly, Haiduc Dale places the self-identification of the Christian communities in the wider historical context of the organization of communal groups in British Palestine. He points out that later in the 1930s Christian intellectuals, mostly writers, started to qualify Christians with the term 'minority,' as a protest to the mandate administration, though they had stressed years earlier that they could not be classified as minorities because they were Arabs first and thus members of the majority population.

The Latin and Melkite (Greek Catholic) communities constituted the majority of the Catholic community of Jerusalem (and to a larger extent, of Palestine). According to the British Mandate censuses of 1922 and 1931, and the numbers that appear in the local archives, ${ }^{44}$ the Latin community was the most numerous in Palestine (a small Melkite community was present in Jerusalem, most of the Melkites resided in Galilee). The Catholic community included only a few Chaldeans, Maronites (14 percent of the Christian population in 1931, more importantly, were primarily located in Galilee) and Armenians ${ }^{45}$ (from ten in 1910 to 500 in 1945, most of them arrived after 1915; they emphasized the Armenian language, the majority of them attended Armenian Orthodox schools, while some attended French Catholic schools). The Melkite community boasted that it was the only Christian community in Palestine that was completely Arab, both laypeople and the clergy; they but recurrently complained that they lacked educational institutions of their own.

As far as private schools were concerned, French Catholic schools were the most numerous; they represented between 75 and 85 percent of the Catholic schools' enrollment during the British Mandate period and more than 60 percent of the private schools enrollment. The French Catholic institutions enrolled the majority of the Christians from Jerusalem until the mid 1920 s and they played an essential diplomatic role in the dissemination both of the French language and Catholicism. Inside the schools, the journals of the educational community reveal several references to communal discussions about the issue of Arabness and local catholicity; the French Catholic brothers also

\footnotetext{
44 COCA, LPA, and SASA.

45 The first vicar arrived in Jerusalem in 1885 , when the residence and the church were built (they have been present at the 4 th station of the Via Dolorosa since 1856).
} 
aimed to educate their pupils in a way that would infuse them with a strong communal identity. Over time, more indigenous teachers (of Arabic but also the sciences) were recruited (not more than 30 percent of the personnel until the beginning of the 1940s).

The number of Catholic schools was disproportionate to the percentage of the population that was Catholic, ${ }^{46}$ and these schools played a key role in raising the educational level of the inhabitants of the Old City. The Collège des Frères, like the one in Jaffa and Caiffa, continued to expand its activities under the British Mandate. We consider these two French Catholic schools as "spaces of encounter" between Christians, Muslims, and Jews and refer to H. Lefebvre's ${ }^{47}$ concept of "space of representation"; according to him the notions of "space of everyday experience" and "spatial practices" appear as central to the functioning of the public sphere, this in contrast to "conceived space." These two schools can be seen as spaces of encounter and spaces dedicated to maintaining the Catholic identity of their pupils.

The Vatican archives reveal the role of the Holy See in the Catholic influence in the Jerusalem public sphere. According to the Vatican, from the beginning of the 1920s, they aimed to establish a 'shared space' between Latin Catholicism and the Oriental Catholic communities and the Muslims. ${ }^{48}$

The Collège des Frères of the New Gate welcomed Christian, Muslim, and a few Jewish pupils (according to the attendance lists, sefaradim represented from 6 to 9 percent of the total school population). ${ }^{49}$ We envisage it as an intermediate space between that devoted to the educational arena and that of the brothers' private communal space, where language choices and language use were discussed, ${ }^{50}$ where it became clear which languages they preferred, they should use, or they simply used.

Sainte Anne's school welcomed Catholic priests and teachers who devoted their time to oriental Catholicism; some of them eventually converted to Greek Catholicism. They discussed the language of the rituals though they functioned under the spiritual jurisdiction of the Latin Patriarchate and the temporal

46 PRO, BB, ED, 38 French Catholic private schools in 1931; 21 British private schools.

47 Andy Merrifield, Henri Lefbvre: A Critical Introduction (London: Routledge, 2006), 109 (and chapter 6 on space).

48 COCA, Melikiti, 2030, Haggear, Ponenza personale. The Bishop evokes the confidence of the Muslims in the Holy See equity and its protection in Palestine.

50 The order of White Fathers was created by the French Cardinal de Lavigerie in Algeria in 1868, some of them specialized in the study of Islam and oriental Catholicism. 
civil authority of the French consul. ${ }^{11}$ The domain of Sainte Anne was French territory where a part of the Nabi Musa procession passes. It faced the eastern entrance to the esplanade of the Dome of the Rock, and played a role in the Palm Sunday procession. When French communal space competed for public space, the procession came from the Mount of Olives to the Church of Sainte Anne, thus reflecting the importance of the linguistic appropriation and promotion: French flags, hymns, pupils associations along with Arab Catholic associations.

During the interwar period, the French consulate set its sights on the growing Jewish population, while at the same time it tried to exert more influence on Catholic school life. The French consulate and the schools, each at their own level, focused on the preservation of the French language. They sought to accomplish this goal by employing a large proportion of French-speaking students in good posts in the administration. They also noted that Jewish and the Muslim pupils were less numerous at the beginning of the 1930s.

\section{Catholics and the Palestinian Nation}

\section{Catholics and the "Modernization"/Neutralism" of the British Government Displayed through the English Language}

The language question in the public/private educational space of Jerusalem can be read as a question of language power, power to bring the inhabitants together or to divide them. The archives of the Catholic schools and the foreign consulates reveal a real consciousness of the power of language on the Jerusalem educational and communal scene. The city embodied the linguistic battle between France and Great Britain; it was a situation that poses the question of the linguistic policy of the British Mandate in Palestine. There was no official linguistic policy, but language planning in the public space can be discerned from the official British discourses on the three communities.

Palestine government officials, through the organization of the governmental school system, argued that a unified school system was undesirable. The desire of the Palestine government to put an end to the Catholic privileges is a

51 During the reception of Cardinal Dubois and the High Commissioner of Beyrouth, the French role towards the Catholics was reaffirmed. The Congrès français de Syrie was established in 1919 to investigate the French interests in the Levant. In its correspondence with the Holy See, the Melkite hierarchy expressed itself in French only, having been trained in French mostly at Sainte Anne, until World War I. 
recurrent theme not only in the schools, but also in the archives of the minister of education, H. Bowman. ${ }^{52}$ The Mandate authorities took direct control of the former Ottoman public schools and nominal control over a plethora of private schools (including those of the Zionist organization). ${ }^{53}$

British administrators claimed that the educational separation of communities along linguistic lines was a pedagogic necessity, a declaration that was well received by Palestinian and Zionist nationalist camps. ${ }^{54}$ Such a policy contributed to the fragmentation of the public space into Jewish and Arab sectors, each with its own 'native' language..$^{55}$ From the official start of the British Mandate in Palestine, the British foresaw their role as the "sacred task of civilization," ${ }^{56}$ which implied a change in language planning and the establishment of an official division of the population into two linguistic groups, an Arabicspeaking group and a Hebrew-speaking group. The formal British Mandate on Palestine was ratified by the League of Nations on 24 July $1922 .{ }^{57}$ Articles 15 and 16 enjoined the Mandate to ensure the rights of the religious communities to maintain schools for the education of their own members. Article 22 of the Mandate recognized English, Arabic, and Hebrew as official languages, ${ }^{58}$ and one year after the Mandate was granted to Britain in Palestine in 1923,

$5^{2}$ COCA, 438, Ingenerenza del Governo inglese nelle scuole cattoliche.

53 Arab governmental schools: 171 in Palestine in 1920 to 403 in 1940; 550 Muslim and Christian private schools.

54 Suzanne Schneider, "Monolingualism and Education in Mandate Palestine," Jerusalem Quarterly 52 (Winter 2013), 68.

55 The British classified Hebrew as a 'mother tongue' in their 1922 census, though, according to Schneider (74, note 3), Hebrew could hardly be classified as anyone's native or mother tongue on the eve of World War I; McCarthy, The Population of Palestine, 82 (inhabitants by mother tongue). Interestingly, schools in Yiddish never gained recognition as public entities "on the ground of that Hebrew was the true native tongue of the Jews," Schneider, "Monolingualism and Education in Mandate Palestine," 71 n. 12. Laura Robson makes the claim that the Mandate authorities made no accommodation for a non-sectarian public space.

56 Laurens, La question de Palestine.

57 РRо, в в, class в Mandate-in contrast to class A Mandate, the в Mandate was not destined for independence; Wolf, "British and French Languages."

$5^{8}$ Article 15 guaranteed "the right of each community to maintain its own schools for the education of its own members in its own language while conforming to such educational requirements of a general nature as the administration may impose." However, the Catholic schools were not recognized as public entities by the British Government, rather they were considered part of the Arab school system. The Education Ordinance, promulgated in 1933, recognized this double educational reality (part 1). 
French, which had previously had the status of a semi-official language, was no longer recognized as the language of examination for all primary, secondary, and professional schools in Palestine. ${ }^{59}$ The Education Department (created in 1922 by the government of Palestine to develop primary education, and secondary, urban, and rural teacher training), although favorable to the religious communities' institutions, separated language from religion in its first piece of legislation and left each community responsible for the teaching of its own religion.

At the beginning of the Mandate, the British administration took little note of education. As the memoirs of the high commissioner Herbert Samuel illustrate, the British-sponsored schools lagged far behind the French schools. At the same time, inside the schools and the entire Mandate administrative, executive, and judiciary spaces, the personnel faced the institutionalization of English. From the archives of the British and the schools, the British educational and linguistic agenda appears as the propagation of an alternative language culture model, the language ideology of the Mandate, as for any colonial power, was to reinforce the power structure, mainly through governmental administration, education, and mass communication. ${ }^{60}$ But more importantly, the Mandate administration seemed to have thought that 'modernization' was inherent in English and synonymous with economic modernity. ${ }^{61}$

The Mandate government was animated by practical considerations: for the government, reading in English was not a cultural exploration but a preparation for entry into life. The Bowman archives reveal that for director of the department of education (1920-1936), another language culture beyond the local vernaculars was perceived as a potential political threat. Humphrey Bowman promoted a doctrine of education along a 'native language line' and wanted to avoid literary education because the linkage of English to the education policy was perceived as a failure, ${ }^{62}$ as the context of English colonial education policy was largely based on the British experience in India. In this respect, Bowman discouraged private and missionary school alternativesabove all he was virulent against the Catholic schools, which were the most numerous not only in Jerusalem but also in the major cities of Palestine-he saw them as institutions of "low calibre."

\footnotetext{
59 AMAE, E 312-32, 26 April 1924.

6o Andrea Stanton, This is Jerusalem Calling: State Radio in Mandate Palestine (Austin: University of Texas Press, 2013).

61 MECA, Humphrey Bowman archives (Director of Education, Mandate Palestine, 19201936), private diary.

62 In 1931, for example, only one in a thousand boys completed secondary education.
} 
At the beginning of his work at the directorate, Humphrey Bowman proposed a state-sponsored binational version of English public schools (Arab children could not be expected to speak Hebrew nor Jewish children to speak Arabic):

the only way in which we can hope to get Jew and Arab [to] work together is to get the children to work and play together and that can be only achieved by having them sit cheek by jowl in the classroom and living in the same school house. As long as the Palestinian Government is carrying out the policy of His Majesty's Government, it is absolutely essential that every effort should be made to get two Semitic divisions to work together ... The language of Arabs is Arabic; the language of the Jews is Hebrew. Both races attach very great importance to the education in elementary schools through their own language. It would be impossible in my opinion to have Arabs and Jews in one school as long as the language difficulty exists and I see no possibility of that language difficulty being solved. ${ }^{63}$

In this context, the French Catholic schools faced a large-scale linguistic change at the beginning of the 1920s: the institutionalization of English and Arabic. But despite the Palestine government pressures, the French Catholic schools did not turn into bilingual (English-Arabic) educational institutions. They continued to value multilingualism.

\section{Language Usage in Catholic Schools}

From the beginning of the 1920s onwards the high commissioner stressed the importance of developing linguistic facility among the employees. Therefore, though the discussions in the French Catholic schools were not about the potential 'anglicization' of their curriculum, they proposed a progressive increase in hours of English instruction.

63 Testimony of H. Bowman, Director of Education, 27 Nov. 1936, in the Palestine Royal Commission Minutes of Evidence Heard at Public Sessions (London: His Majesty's Stationery Office, 1937), cited in Schneider, "Monolingualism and Education in Mandate Palestine," 72. The author stresses the monolingual agenda of the department of education of Palestine. It is only the Palestine Royal Commission that praised the work of a small number of private 'mixed' schools and their form of education as playing a role in bringing the communities together; the government of Palestine never supported this idea. 
The demand for education among the Arab Palestinian population continued to draw pupils to the missionary schools, as the government schools could not offer Palestinian society the opportunities it needed. ${ }^{64}$ They faced a structural problem throughout the period of British Mandatory rule in Palestine, whose budget focused on the problems of defense and counterinsurgencies. Fewer Catholic pupils were enrolled in governmental schools than in other Christian communities (and among them, most of the Melkites attended Catholics schools in the urban areas ${ }^{65}$ ), perhaps because the Latin Patriarchate made several declarations against the so-called 'secular governmental education. ${ }^{66}$ The birth of an urban middle class contributed to the demand for education and emancipation. ${ }^{67}$ Until the mid-1930s, a good education was still based on language education, and foreign languages were still a benchmark, a key factor in obtaining a good social position in Palestinian society. French was essential in education until the mid-1920s because, according to the missionaries, the French government, and the Palestinian elite, it mirrored the "universal values of rationalism and the clarity of expression." 68 That is why enrollment in the French Catholic schools remained stable during the interwar period.

The Catholic school directors questioned the desirability of French and English in their curriculum. Arabic instruction began at the 4th grade, and came to occupy the same number of hours (8 to 12 hours weekly) as French (though some students did not achieve full competence in their native Arabic), followed by English (between 6 and 8 hours a week during the 1930s). In these French Catholic schools, the English language was not used as the primary language in education, in contrast to Terra Santa College (founded in 1926 under the auspices of the Franciscan Custodia di Terra Santa, the second 'secondary' school), and the last grade of the Collège des Frères, which competed with the Arab College, a unique secondary governmental school. ${ }^{69}$ To the 'more

64 Humphrey Bowman, Middle East Window (London: Longmans, Green and Co., 1942), 250254; PRO, BB, DE, annual reports.

65 Most of the Melkite schools were situated in Galilee, and the majority of them were rural boys' schools, whose level was fiercely criticized by the White Fathers of Sainte Anne Seminar in Jerusalem. In the Galilee cities, Latin schools enrolled the majority of the Melkite students, ASSA, Annual reports.

66 LPA, reactions to the education ordinance.

67 In 1935, 1 percent of rural girls enrolled, and 40 percent of urban girls.

68 Reem Bassiouney, Arabic Sociolinguistics (Edinburgh: Edinburgh University Press, 2009), 212.

69 Paolo Pieraccini, Un universita cattolica a Gerusalemme? L'opera cardinal Ferrari e il collegio francescano di Terra Santa, Rivista Antonianum, 81/1 (2006), 135-161. 
and better English' promoted by the Mandate government, the French schools answer was "less and better French." This meant that schools had to manage heterogeneous groups of pupils in language teaching; we see evidence of this in the inspectors' reports. British and Irish Brothers of the Christian schools (Baptiste de la Salle) were sent to Jerusalem to teach English. In June 1930, the director of the Collège des Frères was proud that Keith Roach, then governor of Jerusalem, praised the English teaching level in the school. ${ }^{70}$ English and Arabic, crucial for earning a diploma under the British Mandate, became for the French schools a way of preserving French education and of ensuring that their students found a suitable place in the Palestinian job market. Along with this official language use policy, social activities took place in colloquial Arabic, less curbed during the 1920 s than during the Ottoman period of 'francization.'

Interestingly, French 'national' exams proposed in Catholic schools and in the schools of the Alliance Israélite Universelle (AIU) brought together Jewish teachers of the AIU and the Catholic missionary school teachers, under the umbrella of the French consulate. ${ }^{71}$ The archives reveal one attempt to implement a Hebrew course at the Jerusalem Collège des Frères, in 1934, but the initiative was aborted with the beginning of the Great Arab revolt against the British (summer 1936-1939). ${ }^{72}$ During the period of political turmoil, the Jewish pupils left these schools. ${ }^{73}$

Discussions took place about what was called in French 'l'arabisation des programmes' (the arabization process). ${ }^{74}$ Both schools agreed on the increase of Arabic, progressively insured by professional language Arabic teachers. In Sainte Anne, the discussion also touched on the use of and the teaching of Greek (in the Melkite liturgy and in the curriculum) but the White Fathers

$70 \quad$ ACJ, Rapports, 1928-1933.

71 Ibid.

72 Ibid.

73 Ibid. This was also a result of the position of the Catholic Church towards Zionism. According to a discussion between Weizman and the Secretary of State Gasparri and recorded in the Vatican archives, the Catholic Church believed that Jews could return to Palestine and settle there, but must not act against the interests of other groups. The Holy See negated Zionism as the restoration of the Jewish Gospel revelation and condemned the Zionist 'boldness' that was responsible for the 1928-1929 and 1936-1939 clashes between the communities.

74 For Daphne Tsimhoni, arabization started only after World War II; Christian Communities in Jerusalem and the West Bank since 1948: An Historical, Social, and Political Study (Westport, Ст: Praeger, 1996). 
opted for the reinforcement of Arabic. They followed on this topic the Melkite Patriarch who underlined the importance of Arabic. ${ }^{75}$

Although we do not refer in this chapter to girls' educational space in Jerusalem, it is interesting to mention the case of the girls' Catholic schools because it reveals an interesting interplay between political and educational power of the linguistic agendas of the schools. While like other private girls' schools under the Mandate, Catholic schools intended to educate future good mothers and wives by offering an increase in value on the 'marriage market' (as pointed out by Sasha Goldstein-Sabbah in this volume for the case of Iraq); they also considered languages as fundamental in the identity-building process of young girls. The archives of the German Schmidt's Girls College in Jerusalem, for example, reveal how this German institution used English to promote German and Catholic values to its mixed Christian and Muslim pupil population. ${ }^{76}$ The study of the reactions of the Catholic teachers and pupils at the girls Catholic schools in the public sphere help us to identify the evolution of a common ground: progressively, the Christian girls are perceived to be more free and venture more easily into public spaces than their Muslim peers (the British officials justified the spatial gender segregation as a way of maintaining "harim conditions." $)^{77}$ Catholic girls' schools also reflected the same tensions in Catholic communities, and struggles for loyalty between France and the Holy See. On one hand Christian girls were separated from Muslim girls (concretely, they did not sit on the same benches). On the other hand, the Rosary Sisters that emerged from the order of the French Sisters of Saint Joseph reflected the

75 The few letters of the Melkite Bishop and Archbishop expressing opposition to Sainte Anne evoke this tension around the need to teach in Arabic and consider the seminar school as a 'state' apart ('un Etat dans l'Etat'); Mougabgab, le 13 Dec. 1928 to Sincero.

76 The German cultural and linguistic case is better known in regard to the Ottoman period. In 1885, the Palästina Verein merged with another association and in 1895 became the Deutschen Verein vom Heiligen Land (Order of Saint Vincent). During the Mandate period, the Germans established the second training center for girls after the British administration, almost 100 students, became teachers themselves or got involved at another level, in the educational development of Palestine. The curriculum was proposed in English (German was only a subject). JSSA, Private archives, Schmidts College Jerusalem; for the Ottoman period, Haim Goren, "Echt katholisch und gut deutsch"—Die deutschen Katholiken und Palästina, 1838-1910 (Göttingen: Wallstein Verlag, 2009).

77 Bowman, Middle East Windows, 26o. On segregation in the Sisters of St. Joseph schools in Palestine, AssJ (diaries) and CocA, 451. Ela Greenberg, "Invading Spaces: Challenging the Private-Public Dichotomy in Girls' Education in Mandate Palestine," Hawwa 10, nos. 1-2 (2012), 59 . 
desire of indigenous Catholic nuns to offer an education to Palestinian girls (and in this sense, also preserve the Catholics).

\section{Arabic, Palestinian Nationalism and the Catholic Communities}

At the end of the Ottoman period and during the interwar period, French was presented as a language of coexistence ${ }^{78}$ by several French and indigenous Latin Catholic elites who supported the promotion of an official 'coexistence between communities' in the French boys' schools and girls' schools. ${ }^{79}$ The French missionary schools attempted to find a middle ground between the objectives of the French authorities and the educational and linguistic objectives of Catholic authorities, in order to promote a modus vivendi within the schools. Several Greek Catholic (Melkite) parents criticized this neutral position, as they were more deeply engaged in the Palestinian national movement. ${ }^{80}$

The political context of Mandate Palestine exposed teachers and their pupils to a very public sphere of activism, though most French missionaries avoided talking about 'national feelings.' Politics crept into these two schools, at a time in which British officials believed very few Catholic were active in the Palestinian national movement. The schools did not provide meeting spaces as such to parents and political activity was officially banned, but discussions between parents, pupils, and alumni took place in and outside the schools, more generally in an informal way. The Melkite leaders took a clearer position than the Latin Patriarchate towards Arab nationalism, as the correspondence between the Melkite Church and the Holy See about the 'Palestine Fatherland' makes clear. ${ }^{81}$ The Melkites clearly affirmed that they constituted an integral

${ }_{7} 8$ Few archives among the Central Awqaf archives of Abu Dis mention the warning to parents from the Muslim religious authorities and Jerusalem leaders to beware of the missionary schools. Few cases of intimidation were reported by the directors of the schools, Central Awqaf archives (Abu Dis), 13/25/2, 31/1/75.

79 AMG, NH101, 'Admission des dissidents dans nos écoles', Frère Onésime, Visiteur, 1910. The author of the letter evoked "fewer prejudices ... pupils grateful to their masters and their religion ... segregation and separation cannot offer reconciliation." The girls' schools, providing education to future mothers, played a role in establishing and maintaining 'Christian homes,' while they continued to enroll a large number of Muslim pupils.

80 VSSA, 108 PO 103, 22 Dec. 1929, Apostolic Delegate to the Secretariat of State, Vatican, reaction of Bishop Haggear and vssA, 131 PO 115, Palestina 1932-1936, Centro Internationale per la protezione degli interessi cattolici Minaccia sionista (directors of Catholic schools in the committee).

81 LPA, Correspondance with the Oriental Congregation, o1/1933, 'communion avec le prêtre 
part of the national movement and criticized firmly the 'neutrality' of the European consuls and missionaries. After the increase in tentions between Arabs and Jews that took place in 1928-1929, they moved towards a common ground 'imposed' by the political circumstances in their correspondence with the Holy See:

Our people are Palestinians and they are summoned by Muslims to walk with or against them: neutrality is not allowed. [They] would expose themselves to the greatest dangers if they would not go hand in hand alongside with the Muslims. They are, in fact, a small minority scattered among a large majority of boiling fanaticism. I stand in good relation with Muslims to protect my people. ${ }^{82}$

The French schools' linguistic policy mirrored the interplay of the European powers, which was even stronger after the opening of the YMCA (Young Men's Christian Association) ${ }^{83}$ in May 1933. An analysis of their pedagogical materials shows that a progressively important place was given to local heritage and the figure of the Palestinian Christians. ${ }^{84}$ Some Catholic school magazines emphasized identity as being based on religion, the Arabic language, and local history, and argued that students were able to study French culture or Western culture without losing their identity. 85

Both actors, French and British, imported a language system, and their national languages were appropriated and rejected to different degrees by the Catholic communities. Thus it seems as inadequate to describe Arabic as 'the' language of nationalism, as it is to describe French as simply the language of the protector of the Catholics.

en arabe ... le rite représente l'expression pure et élevée de son idéal national ... il s'attache à son rite comme il s'attache à sa patrie' (interview with a Catholic Belgian newspaper).

82 COCA, Melikiti, 2030, Haggear, Ponenza personale, Letter of Haggear to Sincero (cardinal, Propaganda Fide, 13 Dec. 1929 — in French in the original letter), "Nos fidèles sont des palestiniens et ils sont sommés par les musulmans de marcher avec ou contre eux: la neutralité n'est pas admise. Or nos fidèles s'exposeraient au plus grands dangers s'ils n' allaient pas main dans la main aux côtés des Musulmans. Ils constituent, en effet, une faible minorité éparse au milieu d'une grande majorité bouillante de fanatisme. Je me tiens en bon rapport avec les musulmans afin de protéger mes fidèles."

83 AMAE, Nantes, B, 188 and 200, 18A.

84 ACJ, French language books.

85 ACTS, Magazine of the Terra Sancta (Franciscan) College, 1924-1929. 
Both schools, through their relations with the various ecclesiastical institutions to which they had to pay allegiance (the Vatican, Latin and Melkite Patriarchates) were instructed not to interfere with temporal powers. The Holy See insisted from the early 1920 s that missionaries should remain neutral and should not be "agents of colonial powers"; it emphasized the incompatibility between the roles of language and faith missionaries. ${ }^{86}$ On a number of occasions the Vatican and the Latin Patriarchate insisted that the missionaries' duties not interfere with the temporal powers, and they stated that missionaries should not be "agents of colonial powers," and reproached them for seeming "more concerned about the interests of their country than the salvation of souls." 87

\section{Protecting the Catholics?}

\section{Catholic Communities, the 'Most French Oriental Land' and the}

\section{'Language of Protestantism'}

While the doctrine of papal supremacy and the hierarchical organization of the Catholic community might convey an impression of uniformity in Catholic communal responses, in comparison to the multiple responses of the Anglican and protestant communities; ${ }^{88}$ in fact, Catholic actors displayed diversity at different levels (Rome, French consulate, Latin and Melkite Patriarchates). The terms of the debate over the functions of English, Arabic, and French tended to be formulated between an international language, a humanistic and 'civilization' language, and the language of God.

French Catholic schools had a monopoly when it came to representing France because other linguistic and cultural institutions (Cultural Centre, Mission Laique, Alliance Française ${ }^{89}$ ) had not succeeded in establishing themselves in Palestine. French schools gradually opened their doors to enroll children from the Muslim, and to a lesser extent Jewish, elite. These institutions (primary, secondary, and vocational education) continued to be used as a plat-

86 AMg, Maximum Illud, 30 Nov. 1919, Acta Apostolicae, sedis XI, 440. Nationalism is assimilated to heresia, December 1922, Pie XI, Ubi Arcano Die Consilio.

$87 \quad$ LPA, Circulaire du Patriarche Barlassina, 2 Oct. 1920.

88 Roland Loeffler, Protestanten in Palästina. Religionspolitik, Sozialer Protestantismus und Mission in den deutschen evangelischen und anglikanischen Institutionen des Heiligen Landes 1917-1939 (Stuttgart: Kohlhammer Verlag, 2008).

89 Alliance française ("French Alliance," founded in 1883) or the Mission Laique française (“French Lay Mission," founded in 1902). 
form for French cultural influence and to sponsor Catholic protection, while also providing an alternative to British linguistic and educational initiatives.

Significantly, the arrival of the Crusaders in Jerusalem and the 'prise de la Bastille' by the people of Paris were celebrated every summer on the 14th of July in the French schools. For this reason, the French consulate supported them financially and diplomatically (with annual subsidies, examinations presided over by a panel of French adjudicators, diplomas equivalent to French ones, and negotiations with the Ottoman authorities to obtain their authorization for the teaching and building permits for schools). ${ }^{90}$

Despite heralding the end of the French Catholic protectorate, the early 1920 sere marked by symbolic links between the government and the Catholic religion in France (the canonization of Joan of Arc on 16 May 1920, the completion and consecration of the Basilica of the Sacred Heart in Paris), but also in the East (the visit of Cardinal Dubois to the Levant in 1920 was seen as an appropriation of the French Levant).91

At the beginning of the 1920 s the Vatican and the Latin Patriarchate of Jerusalem condemned the French nationalist attitude towards the Catholic schools, but not the teaching of French. ${ }^{92}$ For the Holy See, this teaching of French along with Arabic, was also, if not mainly intended to resist to 'the language of Protestantism.'

The promotion of the catechism (both text books and religious education) in Arabic was part of a bigger project directed by the French ecclesiastic Abbé Guervin from Amiens and approved by the popes Benedict XV and Pius XI to attempt to preserve the Catholics (via schools, cultural associations, and international organizations) ${ }^{93}$ At the end of the 1920 s the Catholic authorities (both local and in Rome) ${ }^{94}$ required that the French schools implement their

9o AmaE, Nantes, B, 200, 16 Jan. 1918 and AMAE, E 312-1, nº83, A. Guerin to the Minister of Foreign Affairs, 16 Oct. 1920.

91 Dominique Trimbur, "Une appropriation française du Levant-La mission du cardinal Dubois en Orient," in Patrick Cabanel (ed.), Une France en Méditerrannée-Ecoles langue et culture française, XIXe-XXe siècles (Paris: Creaphis, 2006), 109-128.

92 COCA, 465 I Fratelli delle scuole cristiane; 465 I Fratelli delle scuole cristiane, 1671/24 A Sua. Em. Rev.ma Card Camillo Laurenti, Prefetto della s. Congregazione dei Religiosi. vssa, 33, Po. 49, Palestina, 1923-1936, Opera della Preservazione della Fede in Palestina e scuole cattoliche and sco, 481, Opera della preservazione della Fede in Palestina.

94 The Latin Patriarchate, jurisdiction of the Roman Catholic Church in the Middle East was restored on 23 July 1847 (between the period of 1291, after the last Crusaders left the Holy Land, and 1847, the Franciscans were the curators of the Christian Holy places and the legal representatives of the Latin Catholic authorities). 
curricula and develop Arabic teaching rapidly, in order to counter Protestant educational initiatives (in which Arabic played an important role) ${ }^{95}$ The Latin Patriarchate invited the French institutions to improve their teaching of religion in the Arabic language, and invited the missionaries to provide catechism classes only in Arabic. ${ }^{96}$

To promote the international dimension of Catholicism, the Latin Patriarchate and the Vatican supported the creation of the Confrérie du Très Saint Enfant in Bethlehem in 1909, which after only one year became the Archiconfrérie du Très Saint Enfant. Several months after its establishment, this international Catholic association, created by the French Brothers from Christian schools and devoted to the promotion of Catholic values in education, was already recruiting its members from more than 200 countries. Its journal, L'Echo de Bethléem, was published in five languages before the beginning of World War I. ${ }^{97}$

\section{Arabic, the Language of the "Local Catholics"?}

Did the Catholic community view Arabic as a national language and commit to it as such? The newspaper of Bethlehem, Sawt al-sha'b ('the voice of the people'), established by Issa al-Bandak, ${ }^{98}$ was distributed in and around Bethlehem and Jerusalem and to the families of the pupils of these two schools. Different articles reveal one aspect of the Catholic answer to the Palestinian Arab orthodox community claim to be the only 'indigenous' Catholics, emphasizing its 'Arabness.' These articles bring elements on the Catholic movement to assert the rights of the indigenous Catholics in the face of European educational missionary orders, and to promote Arabic and 'national' rights. Several

95 COCA, 466 i Protestanti in Palestina; 504 scuole media di lingua inglese in Palestina (to thwart the Bristish influence); 463 L'ospizio de Tantur, desire to fight against the influence of the YMCA and attract the Catholic youth, but also the other Christians and Muslim youth. LPA, Circulaire du Patriarche Barlassina, 02 Oct. 1920; LPA, General correspondence, 1918-1924, correspondence after the Education Ordinance and the erection of the YMCA, 1933 .

96 AMG, GB351, 1932; AmAE, Nantes, Sofe, no 362,13 Dec. 1941.

97 Karène Sanchez, L'Archiconfrérie du Très Saint Enfant de Palestine ottomane et mandataireSoutiens spirituels internationaux et locaux à la 'croisade pour l'éducation religieuse de l'enfance et la jeunesse' (Paris: Karthala, forthcoming).

98 COCA, Latini, Propaganda Fide, 417, Sawt el Chab no 144, 19 Feb. 1925 (in Arabic) ASCAEs, ss (Archivio della Sacra Congregazione degli Affari Ecclesiastici straordinari Segretario di Stato), Latini e missionari locali chiedono un Patraiarca arabo. 
editions of this newspaper from 1923 to 1925 qualify the Catholics of Palestine as "members of the Palestinian nation, having the same language, traditions, uses ('coutumes') as the Muslim."99

The newspaper also evokes a 'Comité de défense national catholique': the title indicates a possible equation between a communal and a national identification, though we cannot envisage to what extent it represented the Catholic community in all its different components. This committee was presented as acting for the promotion of an indigenous clergy and an Arabic Palestinian patriarchate, to preserve the indigenous interests of the Catholics against the European clergy and to emphasize the use of Arabic "common to Christians and Muslim."100

In their publication, the members of this committee underlined the danger of foreign institutions in Palestine. The correspondence between the Holy See and the Latin Patriarchate on this matter gives us an account of the controversy among indigenous Catholics about European education and European Catholic missionaries, and the feeling of 'annihilation of their rights' this European Catholic presence represented. They denounced the "national and patriotic fanaticism of some Cardinals" and clearly decried the influence of missionary schools and their negative consequences in terms of the identity building process. ${ }^{101}$ With regard to the use of Arabic in Catholic schools, some elements referred to Khalil Sakakini's argument after the opening of the national school Dusturiyya (the 'constitutional school' renamed Wataniyya during the Mandate - a school that used Arabic as the primary language of instruction) in 1909, in which he advocated a largely secular curriculum. ${ }^{102}$

This went along with the creation of the first indigenous educational missionary order, the Rosary sisters. These were Palestinian nuns who originally belonged to the French Catholic order of the Sisters of Saint Joseph and were well established in the Ottoman territories and later Mandate Palestine. The order of the Rosary sisters spread after 1920, and focused on the importance of an indigenous education given mainly in Arabic. During the Mandate period, the foundation and the development of the schools around the Arabic language

99 COCA, 417, Movimento di xenofobismo contro il clero straniero; $\mathrm{n}^{\circ} 2080$, 1927, article Shoura, Caire, $\mathrm{n}^{\mathrm{o}}{ }_{153}, 27$ Oct. $1927 \mathrm{E}$ fino a quando, $\mathrm{n}^{\circ}{ }_{150}, 6$ Oct. 1927 , Cose latine.

100 COCA, Latini, Propaganda Fide, 417, Sawt el Chab, 2 Aug. 1923, Il risorgimento religioso del populo arabo catolico in Palestina.

101 But from 1924 these sensitive discussions ceased to appear, most probably stifled by the Latin Patriarchate.

102 Robson, Colonialism and Christianity in Mandate Palestine, 29-32. 
was praised both by the Holy See and the Latin Patriarchate. ${ }^{103}$ There was not an equivalent for boys.

The Vatican's interest in Arabic as the language of the indigenous Catholics was already present before the beginning of the British Mandate: Arabic had an important position in the curriculum at the Pontifical Institute for Oriental studies, created in 1917 to reinforce the links with the oriental congregations (the expression referred the Greek Catholics who had been united with Rome since 1724, but also referred to the Latin community, mainly converted from Orthodox communities). From the early 1920s, the Holy See expressed the desire to implant itself in the Palestinian landscape via linguistic choices. But while supporting the Catholic community of Palestine and the underlying necessity of addressing it in Arabic in order to address this community in its mother language and to reinforce a common ground with their Muslim fellows, the Holy See emphasized the international Catholic sphere and space, thus detaching, in its declarations, the Catholics from their Muslim Palestinian fellows. ${ }^{104}$

Among the internal discussions in Sainte Anne (between the White Fathers but also with the Melkite hierarchy), some elements underlined the linguistic aspects: the Melkites were considered part of the larger Arabic world and Arabic was needed to dispel Muslim and other Christian stereotypes of Melkites. There was also a need to have a level of Arabic sufficient to engage in theological and philosophical discussions, and that Arabic could be an aspect of the common ground in the discussions with the Greek orthodox community. ${ }^{105}$

Though the Holy See actively supported the Rosary Sisters, it did not support the Catholic National Committee (after 1927, it disappeared from the archives, supposedly eliminated by both the Holy See and the Latin Patriarchate). The variety of the correspondence in the archives leads us to believe that the language choices of the Catholic community were not necessarily just responses to Zionism or efforts to use Islam to mobilize resistance against the British. Intercommunal rivalries between Latin Catholics and Melkites also led to a more nuanced yet unique communal reaction.

103 COCA, 451, Le Suore del Santo Rosario a Gerusalemme, and R. Génier, La congrégation des sœurs du Rosaire de Jérusalem (Paris: J. Gabalda et Compagnie, Paris Librairie Victor Lecoffre, 1913).

104 COCA, 426, Progetti di venire in aiuto dei catholici in Palestina; COCA, 461, Lopera Cardinal Ferrari, $\mathrm{n}^{\mathrm{o}}{ }^{1310}$, Milan is financially supporting the new Catholic institution.

105 SASA, Motifs d' insistance sur la langue arabe. 


\section{Conclusion}

From the mid 1930s onward, the British administration took on the task of bringing the inhabitants of Palestine together via a linguistic program; the task remained unrealized, and had clear consequences in the educational system (the public as well as the private). The protection of the Catholics was an official leitmotiv of French cultural and linguistic policy and then of the Vatican in the Holy Land. Catholics from Palestine were trapped between different policies that influenced linguistic ideologies and practises: the centralizing Catholic interests of Rome which for lay believers first favored French, but later mostly Arabic; the national interests of Catholic European powers present in the Holy Land that favored their own languages along with English from the 1930s onwards; and an Arab majority that favored Arabic over and above French or other western languages.

Until the end of World War II, Catholic schools remained instrumental in shaping Palestinian identities, Christian and Muslim; the schools continued to favor multilingual education, against the monolingual approach of British actors. French remained part of the curriculum but as an inner-worldly ('un bien temporel') rather than a spiritual (universalist Catholic) good, though both Latin and Melkite Catholics praised Arabic as their national language. French should be seen as one element of a complex linguistic and multicultural situation in which linguistic usage depended on context. French coexisted with other foreign languages: Italian, German, and at a later stage English and the linguistic accommodation of the Catholics was a complex process, languages being a symbol and a tool in Mandate Palestine.

Language education policy in Palestine included decisions about which languages were to be used as a medium of instruction and/or taught in schools, and also included analysis, to some extent, of this policy within its social, ethnic, religious, political, cultural, and economic contexts. The repositioning in Catholic communities towards the use of languages and the role of the Vatican in fostering divisions/reconciliations in the Palestinian Catholic community influenced the conceptualization of language as a tool, at the individual and group level. French, Arabic, and English were perceived as symbolic resources in this tiny community, as an instrument to counteract conflict. Further sociohistorical and linguistic study should be undertaken to investigate the issue of the to which extent the Catholic community used a colloquial Arabic different than that of the Muslim and the Yishuv communities.

The resulting 'story' proved to be fragmentary, not only because of its actors' divisions, but also because of the shifting motivations and self-understandings of the Catholic community. There are no unifying narratives that describe 
the behavior and beliefs of the Palestinian Catholic community with regard to the linguistic challenges of the Mandate period and its translations into the public space of Jerusalem, other than to say that local and international actors influenced the way this community engaged with (and was perceived by others). The experience of French missionaries and indigenous Catholics as they relate to language use and perception in Palestine differed in spirit, practice, and results.

The Catholic case illustrates and causes us to reassess the complexity of the functional and symbolic roles of languages in the Middle East between the two world wars. Further studies on the linguistic agenda of the Catholic diaspora and its impact on the Jerusalem scene might reveal other aspects of language use in social, political, and religious processes, of the role of language in affirming or negating political agendas and self-identities in areas of conflict, of the entanglement of language use in conflict situations inside Palestine but also transnationally. A study of the Melkite and Latin responses to the situation in Galilee to the Peel Commission report of 1937 (according to which most Melkite areas would be ceded to the proposed Jewish state) would bring another Catholic sub-narrative on the multifaceted common ground. Finally, the new digitization of archives, like the photographic collection of the Ecole biblique et archéologique of the Dominicans of Jerusalem that contains a vast photographic collection of the Melkite seminar of Sainte Anne, might reveal possible manifestations of common ground in the public spaces of Mandate Jerusalem.

\section{Bibliography}

Aslanov, Cyril. Le français au Levant, jadis et naguère. A la recherche d'une langue perdue. Paris: Honoré Champion, 2006.

Barrès, Maurice. Une Enquête aux Pays du Levant. Paris: Plon-Nourrit, 1923.

Bar-Yosef, Ethan. The Holy Land in English Culture, 1799-1917: Palestine and the Question of Orientalism. Oxford: Clarendon Press, 2005.

Bassiouney, Reem. Arabic Sociolinguistics. Edinburgh: Edinburgh University Press, 2009.

Bowman, Humphrey. Middle East Window. London: Longmans, Green and Co., 1942.

Cabanel, Patrick. "Les deux vocations: catholique ou laïque? La France, le Levant et l' islam." In Religion et identité, edited by Gabriel Audisio, 199-209. Toulouse: Presses de l'Université de Provence, 1998.

Calvet, Louis-Jean. La guerre des langues et les politiques linguistiques. Paris: Payot, 1987 . 
Cuinet, Vital. La Turquie d'Asie, géographie administrative, statistique descriptive et raisonnée de chaque province de l'Asie mineure. Paris: E. Leroux, 1895.

Errington, Joseph. Linguistics in a Colonial World: A Story of Language, Meaning, and Power. Blackwell Publishing, 2008.

Fortna, Benjamin. Imperial Classroom: Islam, the State and Education in the Late Ottoman Empire. Oxford: Oxford University Press, 2002.

Goren, Haim. "Echt katholisch und gut deutsch"-Die deutschen Katholiken und Palästina, 1838-1910. Göttingen: Wallstein Verlag, 2009.

Greenberg, Ela. "Invading Spaces: Chalenging the Private-Public Dichotomy in Girls' Education in Mandate Palestine." Hawwa 10, nos. 1-2 (YEAR?): 59-76.

Haiduc Dale, Noah. "Arab Christians in Palestine Communalism and Nationalism, 19171948." PhD dissertation, New York University, 2010.

Joseph, Brian D. "Historical Linguistics and Sociolinguistics: Strange Bedfellows or Natural Friends?" In Language and History, Linguistics and Historiography, edited by Nils Langer, Steffan Davies, and Wim Vandenbussche. New York: Peter Lang, 2012.

Joseph, John E. Language and Identity, National, Ethnic, Religious. New York: Palgrave Macmillan, 2004.

Khalidi, Rashid. Palestinian Identity, the Construction of a Modern Identity. New York: Columbia University Press, 1997.

Laurens, Henri. La question de Palestine (1922-1947). Une mission sacrée de civilisation. Paris: Fayard, 2002.

Loeffler, Roland. Protestanten in Palästina. Religionspolitik, Sozialer Protestantismus und Mission in den deutschen evangelischen und anglikanischen Institutionen des Heiligen Landes 1917-1939. Stuttgart: Kohlhammer Verlag, 2008.

McCarthy, Justin. The Population of Palestine, Population History and Statistics of the Late Ottoman Period and the Mandate. New York: Columbia University Press, 1988.

Merrifield, Andy. Henri Lefbvre: A Critical Introduction. London: Routledge, 2006.

Myhill, John. Language, Religion and National Identity in Europe and the Middle East. Amsterdam: John Benjamins, 2006.

O'Mahony, Anthony. "The Latins of the East: The Vatican, Jerusalem and the Palestinian Christians." In The Christian Communities of Jerusalem and the Holy Land: Studies in History, Religion and Politics, edited by Anthony O'Mahony, 90-114. Cardiff: University of Wales Press, 2003.

Nicault, Catherine, Jérusalem 1850-1948, des Ottomans aux Anglais, entre coexistence spirituelle et déchirure politique (Paris: Autrement, 1999).

Porath, Yehoshuah. The Emergence of the Palestinian-Arab National Movement, 19181929. London: Cass, 1974.

Riffier, Jean. Les œuvres françaises en Syrie-1860-1923. Paris: L'Harmattan, 2000.

Robson, Laura, Colonialism and Christianity in Mandate Palestine. Austin: University of Texas Press, 2011. 
Sanchez, Karène. L'Archiconfrérie du Très Saint Enfant de Palestine ottomane et mandataire-Soutiens spirituels internationaux et locaux à la 'croisade pour l'éducation religieuse de l'enfance et la jeunesse'. Paris: Karthala, Histoires des mondes chrétiens, pp. $173^{-195}$.

—. "Les catholiques palestiniens et la langue française (1870-1950). Une langue des minorities devenue minoritaire?" In Documents de la SIHFLEs $n^{\circ} 45$, Langue française, identité(s) et école(s): le cas de la minorité catholique au Levant, edited by Karène Sanchez, 17-41. Lyon: ENS, 2011.

Politiques, éducation et identités linguistiques: Le collège des frères des écoles chrétiennes de Jérusalem -1922-1939 (Utrecht: LOT, 2009).

Schillo, Frederique. "Les commerçants français en Palestine pendant la période ottomane." In De Bonaparte à Balfour, la France, l'Europe occidentale et la Palestine, 1799-1917, edited by Dominique Trimbur and Ran Aaronsohn, 135-167. Paris: CNRS editions, 2008.

Schneider, Suzanne. "Monolingualism and Education in Mandate Palestine." Jerusalem Quartely 52 (Winter 2013): 68-74.

Sharkey, Heather. American Evangelicals in Egypt: Missionary Encounters in the Age of Empire. Princeton, NJ: Princeton University Press, 2008.

Sherman, Arie Joshua. Mandate Days: British Lives in Palestine, 1918-1948. Baltimore: Johns Hopkins University Press, 1997.

Spolsky, Bernard and Robert L. Cooper. The Languages ofJerusalem. Oxford: Clarendon Press, 1991.

Stanton, Andrea. This is Jerusalem Calling: State Radio in Mandate Palestine. Austin: University of Texas Press, 2013.

Suleiman, Yasir. "Nationalism and the Arabic Language." In Arabic Socilinguistics: Issues and Perspectives, edited by Yasir Suleiman. Richmond, Surrey, UK: Curzon Press, 1994.

Tamari, Salim and Issam Nassar (eds.). Al-Quds al-intidābiyya fìl-mudhakarāt al-jawhariyya. Jerusalem: Institute of Jerusalem Studies, 2005.

Tamari, Salim. Year of the Locust: A Soldier's Diary and the Erasure of Palestine's Ottoman Past. Berkeley: University of California Press, 2011.

Tibawi, Abdul Latif. Arab Education in Mandatory Palestine: A Story of Three Decades of British Administration. London: Luzac, 1956.

Trimbur, Dominique. "Catholiques français et allemands en Palestine, xıxe-Xxe siècles." Bulletin du Centre de recherche français de Jérusalem 18 (2007) 92-106.

"Sainte Anne, lieu de mémoire et lieu de vie français à Jérusalem." In Chrétiens et sociétés-XVIe-XXe siècles 7 (2000): 39-69.

- "Une appropriation française du Levant_La mission du cardinal Dubois en Orient." In Une France en Méditerrannée-Ecoles langue et culture française, XIXeXxe siècles, edited by Patrick Cabanel, 109-128. Paris: Creaphis, 2006. 
Tsimhoni, Daphne. "The Arab Christians and the Palestinian Arab National Movement during the Formative Stage." In The Palestinians and the Middle East Conflict, edited by G. Ben-Dor, 73-98. Ramat Gan: Turtledove Publishing, 1978.

Christian Communities in Jerusalem and the West Bank since 1948: An Historical, Social, and Political Study. Westport, C T: Praeger, 1993.

Watenpaugh, Keith David. Being Modern in the Middle East: Revolution, Nationalism, Colonialism, and the Arab Middle Class. Princeton, NJ: Princeton University Press, 2006.

White, Benjamin Thomas. The Emergence of Minorities in the Middle East, the Politics of Community in French Mandate Syria. Edinburgh: Edinburgh University Press, 2012.

Wolf, Hans-Georg. "British and French Languages and Educational Policies in the Mandate and Trusteeship Territories." Language Sciences 30, no. 5 (2008): 553-574. 